\title{
PENGARUH MODEL THINK PAIR SHARE BERBASIS TRI HITA KARANA TERHADAP SIKAP PEDULI SOSIAL DAN KOMPETENSI PENGETAHUAN IPA SISWA
}

\author{
Yande Arya Wara Niraha' ${ }^{1}$, D. P. Parmiti², K. Yudiana ${ }^{3}$ \\ 123Jurusan Pendidikan Dasar,Universitas Pendidikan Ganesha, Bali, Indonesia \\ E-mail : arya.wara.niraha@undiksha.ac.id
}

\begin{abstract}
Abstrak
Penelitian yang dilakukan ini bertujuan untuk mengetahui ada dan tidaknya perbedaan yang signfikan 1) sikap peduli sosial, 2) kompetensi pengetahuan siswa dalam muatan pelajaran IPA, 3) sikap peduli sosial dan kompetensi pengetahuan siswa dalam muatan pelajaran IPA secara simultan antara siswa yang dibelajarkan melalui model kooperatif tipe Think Pair Share berbasis Tri Hita Karana dan siswa yang dibelajarkan melalui pembelajaran konvensional. Jenis penelitian ini adalah penelitian semu (quasy exsperiment) dengan rancangan penelitan Non-equivalent Post-test Only Control Group Design. Populasi dari penelitian ini adalah seluruh siswa kelas IV SD Gugus VI Kecamatan Sukasada dengan jumlah Populasi 178 siswa dan sampel dalam penelitian ini berjumlah 89 siswa yang diambil dengan teknik random sampling. Data sikap peduli sosial dikumpulkan mengunakan metode non-tes berupa kuesioner dan kompetensi pengetahuan IPA dikumpulkan mengunakan metode tes pilihan ganda. Data dianalisis dengan statistik deskrptif, inferensial, dan Manova. Hasil penelitian menunjukkan bahwa terdapat perbedaan yang signfikan: 1 ) sikap peduli sosial ( $\mathrm{F}=488,083$ (sig.) sebesar $0,000<$. $0,05), 2$ ) kompetensi pengetahuan siswa dalam muatan pelajaran IPA ( $F=45,059$ (sig.) sebesar $0,000<0,05), 3$ ) sikap peduli sosial dan kompetensi pengetahuan siswa dalam muatan pelajaran IPA secara simultan ( $\mathrm{F}=270,235$ (sig.) sebesar 0,000 < 0,05) antara siswa yang dibelajarkan melalui model kooperatif tipe Think Pair Share berbasis Tri Hita Karana dan siswa yang dibelajarkan melalui pembelajaran konvensional. Maka dapat disimpulkan bahwa model kooperatif tipe Think Pair Share berbasis Tri Hita Karana berpengaruh terhadap sikap peduli sosial dan kompetensi pengetahuan IPA siswa.
\end{abstract}

Kata Kunci: Think Pair Share; Tri Hita Karana; Sikap Peduli Sosial; IPA

\begin{abstract}
Abstrac
This research aims to find out whether there are significant differences 1) social care attitude, 2) competency of students 'knowledge in the content of science lessons, 3) social care attitude and students' knowledge competencies in the content of science lessons simultaneously between students who are taught through the model cooperative type Think Pair Share based on Tri Hita Karana and students who are taught through conventional learning. This type of research is quasy research with a Non-equivalent Post-test Only Control Group Design research design. The population of this study was all fourth grade students of SD Gugus VI Sukasada District with a population of 178 students and the sample in this study amounted to 89 students taken by random sampling technique. Data on social care attitudes were collected using non-test methods in the form of questionnaires and science competency knowledge collected using multiple choice test methods. Data were analyzed by descriptive, inferential, and Manova statistics. The results showed that there were significant differences: 1) social care attitude ( $F=488,083$ (sig.) Of 0,000<.05), 2) competency of students' knowledge in the content of science lessons ( $F=45,059$ (sig.) Of $0,000<0.05$ ), 3) social care attitude and students' knowledge competencies in the content of science lessons simultaneously $(F=270,235$ (sig.) Of $0,000<0,05$ ) between students who are taught through Tri Hita based Think Pair Share type cooperative models Karana and students who are taught through conventional learning. Then it can be concluded that the cooperative model of Think Pair Share based on Tri Hita Karana has an effect on the social care attitude and science competency of students' science.
\end{abstract}

Keywords: Think Pair Share; Tri Hita Karana; Social Care Attitude; Science

\section{PENDAHULUAN}

Penerapan Kurikulum 2013 memberikan perubahan paradigma, dimana pada hasil akhir pembelajaran siswa tidak hanya menguasai pengetahuan tetapi juga menguasai sikap dan keterampilan. Sesuai dengan Standar Kompetensi Lulusan (SKL), sasaran pembelajaran mencakup pengembangan ranah sikap, pengetahuan, dan keterampilan yang dielaborasi untuk setiap satuan pendidikan (Permendikbud No. 22 Tahun 2016). Hal tersebut diperkuat oleh Permendikbud No. 20 Tahun 2016 
yang menyatakan bahwa setiap lulusan satuan pendidikan dasar dan menengah memiliki kompetensi pada tiga dimensi yaitu sikap, pengetahuan, dan keterampilan.

Implementasi Kurikulum 2013 khususnya di sekolah dasar diharapkan dapat meningkatkan kompetensi pengetahuan siswa salah satunya yaitu, Ilmu Pengetahuan Alam (IPA). Sawatowa (2016:3) berpendapat bahwa "IPA merupakan ilmu yang mempelajari tentang peristiwa atau gejala-gejala alam yang disusun secara sistematis yang didasarkan pada hasil percobaan dan pengamatan yang dilakukan oleh manusia." Dengan adanya pembelajaran Ilmu Pengetahuan Alam (IPA) di sekolah dasar hendaknya membuka kesempatan untuk memupuk rasa ingin tahu siswa secara alamiah. Hal ini akan membantu mereka mengembangkan kemampuan bertanya, dan mencari jawaban berdasarkan bukti serta mengembangkan cara berpikir ilmiah, dan siswa diharapkan dapat mengetahui ilmu pengetahauan dapat ditemukan melalui alam dan segala isinya termasuk Bumi, manusia, hewan, dan tumbuhtumbuhan serta menjaga dan melestarikan alam yang dapat diterapkan dalam kehidupan sehari-hari. Dalam kehidupan sosialnya manusia tentu harus memiliki hubungan yang harmonis dengan lingkungan sekitarnya.

Dari hasil observasi pada tanggal 7 Januari 2019 di Gugus VI kecamatan Sukasada yang peneliti lakukan dengan masing-masing wali kelas IV di SD Gugus VI Kecamatan Sukasada dengan jumlah 8 wali kelas, dari 7 sekolah dasar yang ada di Gugus VI Kecamatan Sukasada dalam proses pembelajaran menunjukan bahwa, 1) penerapan model-model pembelajaran yang kurang inovatif dalam mengemas sebuah pembelajaran yang di lakuan oleh guru, 2) siswa sering mengobrol saat proses pembelajaran, 3) guru tidak menggunakan alam sekitar sebagai media, 4) guru tidak memberikan sebuah peenghargaan sebagai sebuah reinforcement, 5) kurangnya partisipasi siswa dalam mengikuti pelajaran, 6) penguasaan kompetensi pengetahuan IPA siswa kelas IV di SD Gugus VI Kecamatan Sukasada yang belum menunjukkan hasil belajar yang optimal sehingga nilai kompetensi pengetahuan IPA siswa tergolong cukup. Hal tersebut bisa dilihat dari nilai UAS IPA semester I di SD Gugus VI Kecamatan Sukasada yang menunjukkan jumlah siswa yang dibawah KKM (Kreteria Ketuntasan Minimum) sebanyak 99 siswa dari 178 siswa sedangkan siswa yang mencapai KKM (Kreteria Ketuntasan Minimum) sebanyak 78 siswa dari 178 siswa dari data tersebut didapatkan bahwa perbandingannya tidak begitu jauh antara jumlah siswa yang mencapai Kriteria Ketuntasan Minimal (KKM) dengan siswa yang belum mencapai Kriteria Ketuntasan Minimal (KKM). Sehingga dapat dikatakan bahwa penguasaan kompetensi pengetahuan IPA siswa kelas IV di SD Gugus VI Kecamatan Sukasada yang belum menunjukkan hasil belajar yang optimal sehingga nilai kompetensi pengetahuan IPA siswa tergolong cukup. Peneliti juga melakukan observasi dan wawancara kepada wali kelas IV masingmasing SD Di Gugus VI Kecamatan Sukasada pada tanggal 28 maret 2019 mengenai sikap peduli sosial diantara siswa di kelas di SD Gugus VI Kecamatan Sukasada. Peneliti menemukan bahwa kurangnya kerja sama antara siswa perempuan dan laki-laki dalam bekerja kelompok, sering adanya perkelahian dikarenakan saling ejek mengejek masalah agama, dan kurangnya sikap satun yang diperlihatkan oleh siswa terhadap wali kelasnya.

Dalam menyikapi permasalahan tersebut peran guru sangatlah penting dalam merancang pembelajaran agar pembelajaran menjadi menarik, aktif, dan memiliki hubungan yang harmonis antara guru dan siswanya. Proses pembelajarana menggunkan kurikulum 2013 guru hendaknya dapat melaksanakannya dengan maksimal, yaitu menggunkan model kooperatif yang relevan dengan kurikulum 2013 dan dapat diterapkan di salah satu muatan pelajaran didalamnya untuk mencapai tujuan pembelajaran yang diharapkan.

Maka dari itu pembelajaran yang diupayakan sesuai dengan kurikulum 2013 adalah dengan menerapkan model kooperatif yang relevan dan bernuansa kearifan loka, salah satunya adalah model kooperatif tipe Think Pair Share berbasis Tri Hita Karana yang diharapkan dapat menumbuhkan dan meninkatkan sikap peduli sosial dan kompetensi pengetahuan IPA. Pembelajaran menggunkan model Think Pair Share merupakan model yang menekankan pada proses belajarnya secara berpasangan yang berpengaruh pada interaksi siswa yang didukung dengan pendapatnya Shoimin (2014:208) berpendapat bahwa model "Think Pair Share adalah suatu model kooperatif yang memberi siswa waktu untuk berpikir dan merespon serta saling bantu satu sama lain. Model ini memperkenalkan ide "waktu berpikir atau waktu tunggu" yang menjadi faktor kuat dalam meningkatkan kemampuan siswa dalam merespon pertanyaan." Model Pembelajaran kooperatif tipe Think Pair Share (TPS) ini memiliki banyak sekali sisi keunggulan dari model pembelajaran ini (Kurniasih dan Berlin, 2015:58), diantaranya 1) 
Model ini dengan sendirinya memberikan kesempatan yang banyak kapada siswa untuk berpikir, menjawab, dan saling membantu satu sama lain, 2) Dapat meningkatkan partisipasi siswa dalam proses pebelajaran, 3) Lebih banyak kesemptan untu kontribusi masing-masing anggota kelompok, 4) Adanya kemudahan interaksi sesame siswa, 5) Lebih mudah dan cepat membentuk kelompoknya, 6) Antara sesama siswa dapat belajar dari siswa lain serta saling menyampaikan idenya untuk diskusikan sebelum disampaikan de dapan kelas, 7) Siswa dapat mengembangkan keterampilan berpikir dan menjawab dalam komunikasi antara satu dengan yang lain, serta bekerja salng membantu dalam kelompok kecil, dan masih banyak lagi ke unggulan dari model kooperatif tipe Think Pair Share.

Pada dasarnya model ini merupakan suatu cara yang efektif untuk membuat variasi suasana pola diskusi kelas. Selain mengunakan model yang relevan guru juga perlu menyisipkan materi pembentukan karakter muatan lokal maka perlu dikombinasikan dengan Tri Hita Karana, yang merupakan kearifan lokal yang ada di Bali yang diajarkan dan diwariskan secara turun temurun oleh masyarakat di Bali. Tri Hita Karana adalah tiga penyebab tercapainya kebahagiaan atau kesejatraan yaitu, parahyangan: keyakinan hubungan manusia dengan Tuhan, pawongan: keyakinan hubungan manusia dengan manusia, dan palemahan: keyakinan hubungan manusia dengan lingkungan/alam Partadjaja (dalam Adnyana dkk, 2017).

Model kooperatif tipe Think Pair Share berbasis Tri Hita Karana merupakan model pembelajaran menggunkan sistem berpasangan yang saling bekerja sama dalam memecahkan suatu masalah yang berkaitan dengan topik materi yang dibahas kemudian di komunikasikan keseluruh pasangan yang lainnya, dan menekankan karakter muatan lokal yakni menjalin hubungan harmonis dengan Tuhan, sesama manusia, dan dengan lingkungannya, sehingga semua sesama pasangan berhasil mencapai tujuan pembelajaran dan memiliki sikap kepedulian sosial yang tinggi sehingga proses pembelajaran yang dilakukan menjadi bermakna.

Berdasarkan uraian tersebut, secara teoretis model kooperatif tipe Think Pair Share berbasis Tri Hita Karana terhadap sikap peduli sosial dan kompetensi pengetahuan IPA, secara empiris perlu dibuktikan melalui penelitian yang berjudul pengaruh model kooperatif tipe Think Pair Share berbasis Tri Hita Karana terhadap sikap pedulian sosial dan kompetensi pengetahuan IPA kelas IV SD Gugus VI Kecamatan Sukasada tahun pelajaran 2018/2019.

Berdasarkan latar belakang yang telah dipaparkan, maka tujuan dari penelitian ini yaitu 1) untuk mengetahui ada dan tidaknya perbedaan yang signfikan sikap peduli sosial antara siswa yang dibelajarkan melalui model kooperatif tipe Think Pair Share berbasis Tri Hita Karana dan siswa yang dibelajarkan melalui pembelajaran konvensional, 2) untuk mengetahui ada dan tidaknya perbedaan yang signfikan kompetensi pengetahuan siswa dalam muatan pelajaran IPA antara siswa yang dibelajarkan melalui model kooperatif tipe Think Pair Share berbasis Tri Hita Karana dan siswa yang dibelajarkan melalui pembelajaran konvensional, 3) untuk mengetahui ada dan tidaknya perbedaan yang signifikan sikap peduli sosial dan kompetensi pengetahuan siswa dalam muatan pelajaran IPA secara simultan antara siswa yang dibelajarkan melalui model kooperatif tipe Think Pair Share berbasis Tri Hita Karana dan siswa yang dibelajarkan melalui pembelajaran konvensional pada kelas IV di SD Gugus VI Kecamatan Sukasada tahun ajaran 2018/2019.

\section{METODE}

Pelaksanaan penelitian dilakukan di SD Gugus VI Kecamatan Sukasada, Kabupaten Buleleng, Provinsi Bali. Waktu Penelitian dilaksanakan mulai dari bulan April sampai dengan bulan Mei tahun 2019, pada semester II (genap) Tahun Pelajaran 2018/2019. Penelitian ini pada dasarnya bertujuan untuk mengetahui ada dan tidaknya perbedaan yang signfikan 1) sikap peduli sosial, 2) kompetensi pengetahuan, dan 3) sikap peduli sosial dan kompetensi pengetahuan siswa dalam muatan pelajaran IPA secara simultan antara siswa yang dibelajarkan melalui model kooperatif tipe Think Pair Share berbasis Tri Hita Karana dan siswa yang dibelajarkan melalui pembelajaran konvensional pada kelas IV di SD Gugus VI Kecamatan Sukasada tahun ajaran 2018/2019. Penelitian yang dilaksanakan ini merupakan penelitian kuantitatif dengan jenis penelitian yaitu eksperimen semu (Quasy experiment), dan desain yang digunakan yaitu non-equivalent post-test only control group design. Untuk kelompok eksperimen dibelajarkan melalui model kooperatif tipe Think Pair Share bebasis Tri Hita Karana, sedangkan untuk kelompok kontrol dibelajarkan melalui pembelajaran kovensional. 
Populasi dalam penelitian ini adalah seluruh siswa kelas IV SD Gugus VI Kecaman Sukasada tahun pelajaran 2018/2019 yang berjumlah 178 siswa yang terdiri dari yang terdiri atas 8 kelas dari 7 SD. Pengambilan sampel dalam penelitian ini menggunkan teknik sampling acak (random sampeling), dari hasil random sampeling didapatkan kelas IV A dan B SD Negeri 1 Panji Anom yang berjumlah 47 siswa dan kelas IV SD Negeri 2 tegalinggah yang berjumlah 42 siswa.

Variabel dalam penelitian ini terdiri dari satu variabel bebas (independen) dan dua variabel terikat (dependen). Variabel bebas (independen) dalam penelitian ini adalah model kooperatif tipe Think Pair Share berbasis Tri Hita Karana, sedangkan variabel terikat (dependen) dalam penelitian ini adalah sikap peduli sosial dan kompetensi pengetahuan IPA.

Metode yang digunakan untuk mengumpulkan data sikap peduli sosial dalam penelitian ini menggunakan metode non-tes berupa lembar kuesioner sikap peduli sosial yang digunakan dalam penelitian ini menggunkan skala liket 1-5, yang telah diuji validitas, dan reliabilitas, sedangkan kompetensi pengetahuan IPA dalam penelitian ini menggunakan metode tes berupa tes kompetensi pengetahuan IPA dalam bentuk tes objektif dengan tipe pilihan ganda biasa, yang disertai dengan empat alternatif jawaban yang dapat dipilih siswa (a,b,c, dan d), yang telah diuji validitas, reliabilitas, daya beda, dan tingkat kesukarannya.

Teknik analisis yang digunkan untuk menganalisis data hasil penelitian ada dua, yaitu yang pertama analisis statistik deskriftif Koyan (2012:4) menyatakan bahwa "statistik deskriptif" yaitu statistik yang digunakan untuk menggambarkan atau menganalisis suatu statistik hasil penelitian tetapi tidak digunakan untuk generalisasi/inferensi." Pendeskripsian data untuk sikap peduli sosial dan kompetensi pengetahuan IPA siswa dilakukan berdasarkan tendesi data, meliputi mean, varian, dan standar deviasi, dan yang ke dua analisis statistik inferensial penelitian ini terdiri dari uji normalitas sebaran data, uji homogenitas varians, dan uji korelasi antar variabel terikat, kemudian dilanjutkan dengan analisis manova untuk menguji hipotesis. Teknik analisis Anava A pada hipotesis 1 dan 2 sedangkan hipotesis 3 mengunkan teknik analisis Manova dapat digunakan jika data telah memenuhi uji analisis inferensial.

\section{HASIL DAN PEMBAHASAN}

Berdasarkan data sikap peduli sosial dan kompetensi pengetahuan IPA pada kelompok eksperimen yaitu siswa kelas IV SD Negeri 2 Tegalinggah dan kelompok kontrol yaitu siswa kelas IV SD Negeri 1 Panji Anom. Untuk mengukur Sikap Peduli Sosial siswa yaitu menggunakan lembar kuesioner sikap peduli sosial. Lembar kuesioner terdiri dari pernyataan positif dan pernyataan negatif yang secara keseluruhan terdiri dari 30 butir pernyataan. Rentangan skor sikap peduli sosial adalah 30-150 skor 30 merupakan skor minimal dan skor 150 merupakan skor maksimal, sedangkan kompetensi pengetahuan IPA siswa akan diukur menggunakan tes kompetensi pengetahuan IPA dalam bentuk tes obyektif. Setiap butir soal disertai dengan empat alternatif jawaban yang akan dipilih siswa (a,b,c, dan d) dengan jumlah pertanyaan yaitu 30 butir soal, yang diberikan setelah 6 kali perlakuan baik di kelompok eksperimen maupun di kelompok kontrol. Bayaknya siswa yang dianalisis data post-test sikap peduli sosial dan kompetensi pengetahuan IPA pada kelompok eksperimen sebanyak 42 siswa dan pada kelompok kontrol sebanyak 47 siswa.

Dari hasil analisis deskriptif tentang sikap peduli sosial siswa yang dibelajarkan melalui model kooperatif tipe Think Pair Share (kelompok eksperimen) memperoleh skor minimum $=118$, sekor maksimum $=129$, mean (rata-rata) $=123,98$, simpangan baku $(S D)=2,718$ dan varians $=7,390$, Sedangkan hasil analisis deskriptif tentang sikap peduli sosial siswa yang dibelajarkan melalui pembelajaran konvensional (kelompok kontrol) memperoleh skor minimum $=106$, sekor maksimum $=$ 117 , rentang skor $=11$, mean (rata-rata) $=110,72$, simpangan baku $(S D)=2,917$ dan varians $=8,509$. Berdasarkan data tersebut diketahui bahwa perolehan nilai mean (rata-rata) sikap peduli sosial pada kelompok eksperimen yaitu 123,98 > 110,72 pada kelompok kontrol sehingga kelompok eksperimen memiliki nilai mean (rata-rata) sikap peduli sosial lebih tinggi daripada nilai mean (rata-rata) sikap peduli sosial kelompok kontrol.

Dari hasil analisis deskriptif tentang kompetensi pengetahuan IPA siswa yang dibelajarkan melalui model kooperatif tipe Think Pair Share berbasis Tri Hita Karana (kelompok eksperimen) memperoleh skor minimum $=17$, sekor maksimum $=27$, rentang skor $=10$, mean (rata-rata) $=22,93$, simpangan baku (SD) $=2,663$ dan varians $=7,092$ sedangka hasil analisis deskriptif tentang tentang kompetensi pengetahuan IPA siswa yang dibelajarkan melalui pembelajaran konvensional memperoleh skor 
minimum $=14$, sekor maksimum $=25$, rentang skor $=11$, mean (rata-rata) $=19,04$, simpangan baku $(S D)=2,782$ dan varians $=7,737$. Berdasarkan data tersebut diketahui bahwa perolehan nilai mean (rata-rata) kompetensi pengetahuan IPA pada kelompok eksperimen yaitu 22,93 > 19,04 pada kelompok kontrol sehingga kelompok eksperimen memiliki nilai mean (rata-rata) kompetensi pengetahuan IPA lebih tinggi daripada nilai mean (rata-rata) kompetensi pengetahuan IPA kelompok kontrol.

Analisis uji hipotesis dilakukan dengan menggunkan teknik analisis Anava A pada hipotesis 1 dan 2 sedangkan hipotesis 3 mengunkan teknik analisis Manova. Sebelum melakukan uji hipotesis terlebih dahulu harus dilakukan analisis statistik inferensial yang meliputi uji normalitas sebaran data, uji homogenitas varians, dan uji korelasi antar variabel terikat. Uji normalitas sebaran data menggunakan skor dari data sikap peduli sosial dan kompetensi pengetahuan IPA siswa baik dari kelompok eksperimen maupun kelompok kontrol. Uji normalitas sebaran data sikap peduli sosial dan kompetensi pengetahuan IPA siswa menggunakan SPSS 25.0 for windows uji statistik Kolmonogov-smirnov pada signifikansi 0,05 dengan kriteria pengujian adalah data berdistribusi normal jika angka signifikansi (sig.) > 0,05. Dari hasil analisis menggunakan SPSS 25.0 for windows uji statistik Kolmonogov-smirnov pada signifikansi 0,05 diperoleh hasil sebaran data sikap peduli sosial kelompok eksperimen mempunyai nilai signifikansi (sig.) sebesar 0,015. Ini berarti 0,015 $>0,05$ jadi data sikap peduli sosial kelompok eksperimen berdistribusi normal. Pada kelompok kontrol diperoleh hasil sebaran data sikap peduli sosial mempunyai nilai signifikansi (sig.) sebesar 0,041. Ini berarti 0,041>0,05 jadi data sikap peduli sosial kelompok kontrol berdistribusi normal. Uji normalitas sebaran data kompetensi pengetahuan IPA siswa kelompok eksperimen mempunyai nilai signifikansi (sig.) sebesar 0,011. Ini berarti 0,011 > 0,05 jadi data kompetensi pengetahuan IPA siswa kelompok eksperimen berdistri busi normal. Pada kelompok kontrol diperoleh hasil sebaran data kompetensi pengetahuan IPA mempunyai nilai signifkansi (sig.) sebesar 0,072. Ini berarti 0,075 >0,05, jadi data data kompetensi pengetahuan IPA siswa kelompok kontrol berdistribusi normal. Setelah data sikap peduli sosial dan kompetensi pengetahuan IPA siswa baik dari kelompok eksperimen maupun kelompok kontrol dinyatakan berdistribusi normal, maka dilanjutkan dengan analisis uji homogenitas varian data antara kelompok eksperimen maupun kelompok kontrol menggunakan SPSS 25.0 for windows. Uji homogenitas varians yang digunakan adalah uji Levene's test of Equality of Error Varians dengan kriteria data dikatakan memiliki varian yang homogen jika nilai probabilitasnya lebih dari 0,05. Berdasarkan hasil analisis yang diperoleh sikap peduli sosial mempunyai nilai signifkansi (sig.) sebesar 0,633 dan hasil analisis yang diperoleh kompetensi pengetahuan IPA mempunyai nilai signifkansi (sig.) sebesar 1,000. Ini berarti nilai signifkansi (sig.) sikap peduli sosial dan kompetensi pengetahuan IPA $>$ dari 0,05 jadi varian data sikap peduli sosial dan kompetensi pengetahuan IPA kelompok eksperimen dan kelompok kontrol adalah homogen. Setelah itu, dilanjutkan dengan mencari homogenitas matriks varian/covarian dilihat dari hasil uji Box's M sebagai syarat uji analisis hipotesis dengan kriteria bila nilai Box's M signifikansi (sig.) > 0,05 maka hasil uji Box's M signifikan. Dari hasil analisis didapatkan harga Box's M adalah 1,212 dengan signifikan 0,758. Apabila diterapkan signifikansi 0,05, maka 0,758 >0,05 ini berarti signifikan, sehingga analisis MANOVA (Multivariate Analysis of Varians) dapat dilanjutkan. Selanjutnya, uji korelasi antar variabel terikat mengunakan rumus product moment dengan keriteria signifikansi $\mathrm{r}_{\mathrm{xy}}<$ tabel sehingga dapat dikatakan bahwa tidak berkorelasi begitu juga selanjutnya. Dari hasil perhitungan didapatkan hasil kelompok eksperimen korelasinya adalah 0,073 dan kelompok kontrol adalah 0,135 jika di bandingkan dengan $r$ tabel sebesar 0,206 nilai korelasi lebih kecil dengan $r$ tabel, maka dapat disimpulkan bahwa tidak terdapat korelasi antar variabel terikat, sehingga analisis dapat dilanjutkan dengan menggunakan MANOVA (Multivariate Analysis of Varians).

Hasil uji inferensial yang telah dilaksanakan menunjukkan bahwa data sikap peduli sosial dan kompetensi pengatahuan IPA pada kelompok eksperimen maupun kelompok kontro sudab berdistri busi normal, vasian yang homogen, Boxs'M siginfikan, pada variabel trikat pada masing-masig kelompok eksperimen dan kontrol sudah tidak berkorelasi. Maka dari itu telah memenuhi syarat sehingga uji hipotesi dapat dilakukan. Hipotesis dalam penelitian ini pada hipotesis 1 dan 2 diuji mengunakan teknik Anava A dengan bantuan SPSS 25.0 for windows. Adapun kriteria pengujian adalah apabila f dengan signifikansi kurang dari 0,05 maka $\mathrm{H}_{0}$ ditolak dan dan $\mathrm{H}_{1}$ diterima begitu juga sebaliknya, dan hipotesi 3 mengunkan uji analisis Manova dengan bantuan SPSS 25.0 for windows. Adapun kriteria pengujian adalah apabila f dengan signifikansi kurang dari 0,05 maka $\mathrm{H}_{0}$ ditolak dan dan $\mathrm{H}_{1}$ diterima begitu juga 
sebaliknya. Dari hasil analisis uji hipotesis 1 mengunakan analisis Anava A diperoleh hasil yang disajikan pada Tabel. 01 sebaga berikut.

Tabel 1. Hasil Uji Hipotesis 1 dengan Uji analisis ANAVA A

\begin{tabular}{ccccccc}
\hline \multicolumn{7}{c}{ Tests of Between-Subjects Effects } \\
\hline & $\begin{array}{c}\text { Type III Sum } \\
\text { of Squares }\end{array}$ & Df & Mean Square & F & Sig. \\
Dependent Variable & 3895,575 & 1 & 3895,575 & 488,083 &, 000 \\
\hline Sikap_Peduli_Sosial & &
\end{tabular}

Berdasarkan hasil analisis uji hipotesis 1 dengan uji analisis ANAVA A pada Tabel. 01 di atas tampak bahwa koefisien F sebesar 488,083 dengan signifikansi (sig.) sebesar 0,000. Apabila diterapkan taraf signifikansi 0,05. Maka nilai signifikansi jauh lebih kecil dari pada 0,05 yang berarati $\mathrm{H}_{0}$ ditolak dan $\mathrm{H}_{1}$ diterima. Berdasarkan hasil analisis hipotesis 1 dapat diambil kesimpulan yakni terdapat perbedaan yang signfikan sikap peduli sosial antara siswa yang dibelajarkan melalui model kooperatif tipe Think Pair Share berbasis Tri Hita Karana dan siswa yang dibelajarkan melalui pembelajaran konvensional pada kelas IV di SD Gugus VI Kecamatan Sukasada tahun ajaran 2018/2019. Selanjutnya dilakukan uji hipotesis 2 mengunkan analisi Anava A diperoleh hasil yang disajikan pada Tabel. 02 sebagai berikut.

Tabel 2. Hasil Uji Hipotesis 2 dengan Uji analisis ANAVA $A$

\begin{tabular}{lcccccr}
\hline \multicolumn{5}{c}{ Tests of Between-Subjects Effects } \\
\hline & $\begin{array}{c}\text { Type III Sum } \\
\text { of Squares }\end{array}$ & Df & Mean Square & F & Sig. \\
Dependent Variable & 334,940 & & 1 & 334,940 & 45,059 &, 000 \\
\hline $\begin{array}{l}\text { Kompetensi_Pengetahua } \\
\text { n_IPA }\end{array}$ & & & & & & \\
\hline
\end{tabular}

Berdasarkan hasil analisis uji hipotesis 2 dengan uji analisis ANAVA A pada Tabel. 02 di atas, tampak bahwa koefisien F sebesar 45,059 dengan signifikansi (sig.) sebesar 0,000. Apabila diterapkan taraf signifikansi 0,05. Maka nilai signifikansi jauh lebih kecil dari pada 0,05 yang berarati $\mathrm{H}_{0}$ ditolak dan $\mathrm{H}_{1}$ diterima. Berdasarkan hasil analisis hipotesis 2 dapat diambil kesimpulan yakni terdapat perbedaan yang signfikan kompetensi pengetahuan siswa dalam muatan pelajaran IPA antara siswa yang dibelajarkan melalui model kooperatif tipe Think Pair Share berbasis Tri Hita Karana dan siswa yang dibelajarkan melalui pembelajaran konvensional pada kelas IV di SD Gugus VI Kecamatan Sukasada tahun ajaran 2018/2019. Selanjutnya uji hipotesis 3 mengunkan analisi Manova diperoleh hasil yang disajikan pada Tabel. 03 sebagai berikut. 
Jurnal Adat dan Budaya Vol. 1, No. 1, Tahun 2019, pp. 26-34

Tabel. 03 Hasil Uji Hipotesis 3 dengan Uji analisis Manova

\begin{tabular}{llrrrrr}
\hline \multicolumn{7}{c}{ Multivariate Tests $^{\mathbf{a}}$} \\
\hline Effect & \multicolumn{7}{c}{ Value } & \multicolumn{1}{c}{ F } & Hypothesis df & Error df & \multicolumn{1}{c}{ Sig. } \\
\hline Kelas & Pillai's Trace &, 863 & $270,235^{\mathrm{b}}$ & 2,000 & 86,000 &, 000 \\
\cline { 2 - 7 } & Wilks' Lambda &, 137 & $270,235^{\mathrm{b}}$ & 2,000 & 86,000 &, 000 \\
\cline { 2 - 7 } & Hotelling's Trace & 6,285 & $270,235^{\mathrm{b}}$ & 2,000 & 86,000 &, 000 \\
\cline { 2 - 7 } & Roy's Largest Root & 6,285 & $270,235^{\mathrm{b}}$ & 2,000 & 86,000 &, 000 \\
\hline
\end{tabular}

Berdasarkan hasil analisis uji hipotesis 3 dengan uji analisis MANOVA pada Tabel. 03 di atas, tampak bahwa koefisien F sebesar 270,235 dengan signifikansi (sig.) sebesar 0,000. Apabila diterapkan taraf signifikansi 0,05. Maka nilai signifikansi jauh lebih kecil dari pada 0,05 yang berarati $\mathrm{H}_{0}$ ditolak dan $\mathrm{H}_{1}$ diterima. Berdasarkan hasil analisis hipotesis 3 dapat diambil kesimpulan yakni terdapat perbedaan yang signifikan sikap peduli sosial dan kompetensi pengetahuan siswa dalam muatan pelajaran IPA secara simultan antara siswa yang dibelajarkan melalui model kooperatif tipe Think Pair Share berbasis Tri Hita Karana dan siswa yang dibelajarkan melalui pembelajaran konvensional pada kelas IV di SD Gugus VI Kecamatan Sukasada tahun ajaran 2018/2019.

Pada penelitian ini ada tiga hal yang di bandingkan yaitu, 1) sikap peduli sosial antara siswa yang dibelajarkan melalui model kooperatif tipe Think Pair Share berbasis Tri Hita Karana dan siswa yang dibelajarkan melalui pembelajaran konvensional pada kelas IV di SD Gugus VI Kecamatan Sukasada tahun ajaran 2018/2019, 2) kompetensi pengetahuan siswa dalam muatan pelajaran IPA antara siswa yang dibelajarkan melalui model kooperatif tipe Think Pair Share berbasis Tri Hita Karana dan siswa yang dibelajarkan melalui pembelajaran konvensional pada kelas IV di SD Gugus VI Kecamatan Sukasada tahun ajaran 2018/2019, dan 3) sikap peduli sosial dan kompetensi pengetahuan siswa dalam muatan pelajaran IPA secara simultan antara siswa yang dibelajarkan melalui model kooperatif tipe Think Pair Share berbasis Tri Hita Karana dan siswa yang dibelajarkan melalui pembelajaran konvensional pada kelas IV di SD Gugus VI Kecamatan Sukasada tahun ajaran 2018/2019. Hasil dalam penelitian ini menunjukkan pada :

Temuan pertama penelitian ini pada hipotesis 1 (pertama) dengan uji analisis Anava $A$ menunjukkan terdapat perbedaan yang signfikan sikap peduli sosial antara siswa yang dibelajarkan melalui model kooperatif tipe Think Pair Share berbasis Tri Hita Karana dan siswa yang dibelajarkan melalui pembelajaran konvensional pada kelas IV di SD Gugus VI Kecamatan Sukasada tahun ajaran 2018/2019 dari sebaran skor rata-rata (mean) sikap peduli sosial kelompok eksperimen didapat hasil sebaran sebesar 123,98, sedangkan dari kelompok kontrol didapat hasil sebaran sebesar 110,72. Hal ini menunjukkan bahwa sikap peduli sosial siswa yang dibelajarkan melalui model kooperatif tipe Think Pair Share berbasis Tri Hita Karana (kelompok eksperimen) lebih tinggi jika di bandingkan dengan siswa yang kelompok kontrol yang dibelajarkan melalui pembelajaran konvensional pada kelas IV di SD Gugus VI Kecamatan Sukasada tahun ajaran 2018/2019.

Temuan kedua penelitian ini pada hipotesis 2 (kedua) dengan uji analisis Anava A menunjukkan terdapat perbedaan yang signfikan kompetensi pengetahuan siswa dalam muatan pelajaran IPA antara siswa yang dibelajarkan melalui model kooperatif tipe Think Pair Share berbasis Tri Hita Karana dan siswa yang dibelajarkan melalui pembelajaran konvensional pada kelas IV di SD Gugus VI Kecamatan Sukasada tahun ajaran 2018/2019. Dari sebaran skor rata-rata (mean) kopetensi pengetahuan IPA siswa yang siswa yang dibelajarkan melalui model kooperatif tipe Think Pair Share berbasis Tri Hita Karana (kelompok eksperimen) sebesar 22,93 dan siswa yang dibelajarkan melalui pembelajaran konvensional (kelompok kontrol) sebesar 19,04. Hal ini menunjukkan kompetensi pengetahuan IPA siswa IPA siswa yang siswa yang dibelajarkan melalui model kooperatif tipe Think Pair Share berbasis Tri Hita Karana (kelompok eksperimen) lebih tinggi jika dibandingkan dengan siswa yang dibelajarkan melalui pembelajaran konvensional (kelompok kontrol) pada kelas IV di SD Gugus VI Kecamatan Sukasada tahun ajaran 2018/2019.

Temuan ketiga penelitian ini pada hipotesis 3 (ketiga) dengan uji analisis MANOVA yakni terdapat perbedaan yang signifikan sikap peduli sosial dan kompetensi pengetahuan siswa dalam muatan pelajaran IPA secara simultan antara siswa yang dibelajarkan melalui model kooperatif tipe Think Pair Share berbasis Tri Hita Karana dan siswa yang dibelajarkan melalui pembelajaran konvensional pada 
kelas IV di SD Gugus VI Kecamatan Sukasada tahun ajaran 2018/2019. Dari analisi deskriptif tentang sikap peduli sosial dan kompetensi pengetahuan IPA siswa menunjukkan bahwa 1) rata-rata (mean) skor sikap peduli sosial siswa yang dibelajarkan melalui model kooperatif tipe Think Pair Share berbasis Tri Hita Karana (kelompok eksperimen lebih tinggi jika dibandingkan dengan siswa yang dibelajarkan melalui pembelajaran konvensional (kelompok kontrol), 2) rata-rata (mean) kompetensi pengetahuan IPA siswa yang dibelajarkan melalui model kooperatif tipe Think Pair Share berbasis Tri Hita Karana (kelompok eksperimen lebih tinggi jika dibandingkan dengan siswa yang dibelajarkan melalui pembelajaran konvensional (kelompok kontrol). Ini berarti bahwa sikap peduli sosial dan kompetensi pengetahuan IPA siswa yang dibelajarkan melalui model kooperatif tipe Think Pair Share berbasis Tri Hita Karana lebih tinggi jika dibandingkan dengan siswa yang dibelajarkan melalui pembelajaran konvensional pada kelas IV di SD Gugus VI Kecamatan Sukasada tahun ajaran 2018/2019.

Perbedaan yang signifikan ini dikarenakan perbedaan perlakuan terhadap kelompok eksperimen dan kelompok kontrol. Pada kelompok eksperimen dibelajarkan melalui model kooperatif tipe Think Pair Share berbasis Tri Hita Karana. Pembelajaran menggunkan model Think Pair Share merupakan model yang menekankan pada proses belajarnya secara berpasangan yang berpengaruh pada interaksi siswa yang didukung dengan pendapatnya Kurniasaih dan Berlin (2015:58) mereka berpendapat bahwa "Think Pair Share (TPS) atau berpikir berpasangan adalah jenis pembelajaran yang kooperatif yang di rancang untuk mempengaruhi pola interaksi siswa." Pada dasarnya model ini merupakan suatu cara yang efektif untuk membuat variasi suasana pola diskusi kelas. Agar proses pembelajaran yang dilaksanakan berjalan dengan maksimal, maka perlu dikombinasikan dengan Tri Hita Karana, yang merupakan kearifan lokal yang ada di Bali yang diajarkan dan diwariskan secara turun temurun oleh masyarakat di Bali yang bertujuan untuk saling bekerja sama dalam memecahkan suatu masalah yang berkaitan dengan topik materi yang dibahas kemudian di komunikasikan keseluruh pasangan yang lainnya, dan menekankan karakter muatan lokal yakni menjalin hubungan harmonis dengan Tuhan, sesama manusia, dan dengan lingkungannya, sehingga semua sesama pasangan berhasil mencapai tujuan pembelajaran dan memiliki sikap kepedulian sosial yang tinggi sehingga proses pembelajaran yang dilakukan menjadi bermakna. sedangkan pada kelompok kontrol dibelajarkan melalui pembelajaran konvensional pada proses pembelajaran delakukan penyampaian sejumlah materi kemudan diseling tanya jawab kemudian diikut pemberian tugas yang dikerjakan secara mandiri pembelajaran yang seperti ini membuat siswa merasa bosan dan jenuh sehingga sulit untuk memahami materi pemebelajaran. Dari paparan diatas maka dapat disimpulkan bahwa model kooperatif tipe Think Pair Share berbasis Tri Hita Karana berpengaruh terhadap sikap peduli sosial dan kompetensi pengetahuan IPA siswa.

\section{KESIMPULAN DAN SARAN}

Berdasarkan hasil penelitian dan pembahasan, maka dapat disimpukan bahwa model kooperatif tipe Think Pair Share berbasis Tri Hita Karana berpengaruh terhadap sikap peduli sosial dan kompetensi pengetahuan IPA siswa kelas IV Gugus VI Kecamatan Sukasada tahun pelajaran 2018/2019. Hal ini dibuktikan dengan hasil hipotesi 1 yakni koefisien F sebesar 488,083 dengan signifikansi (sig.) sebesar 0,000. Apabila diterapkan taraf signifikansi 0,05. Maka nilai signifikansi jauh lebih kecil dari pada 0,05 dan dilihat dari sebaran skor rata-rata (mean) sikap peduli sosial kelompok eksperimen didapat hasil sebaran sebesar 123,98, sedangkan dari kelompok kontrol didapat hasil sebaran sebesar 110,72, selanjutnya pada hipotesis 2 menunjukkan harga $\mathrm{F}$ variabel terikat kompetensi pengetahuan IPA sebesar 45,059 dengan signifikansi (sig.) sebesar 0,000. Apabila diterapkan taraf signifikansi 0,05. Maka nilai signifikansi jauh lebih kecil dari pada 0,05 dan dilihat dari sebaran skor rata-rata (mean) kopetensi pengetahuan IPA siswa yang siswa yang dibelajarkan melalui model kooperatif tipe Think Pair Share berbasis Tri Hita Karana (kelompok eksperimen) sebesar 22,93 dan siswa yang dibelajarkan melalui pembelajaran konvensional (kelompok kontrol) sebesar 19,04, dan pada hipotesis 3 menunjukkan harga F sebesar 270,235 $\mathrm{b}$ dengan signifikansi (sig.) sebesar 0,000. Apabila diterapkan taraf signifikansi 0,05. Maka nilai signifikansi jauh lebih kecil dari pada 0,05 dan dilihat dari 1) rata-rata (mean) skor sikap peduli sosial siswa yang dibelajarkan melalui model kooperatif tipe Think Pair Share berbasis Tri Hita Karana (kelompok eksperimen lebih tinggi jika dibandingkan dengan siswa yang dibelajarkan melalui pembelajaran konvensional (kelompok kontrol), 2) rata-rata (mean) kompetensi pengetahuan IPA siswa yang dibelajarkan melalui model kooperatif tipe Think Pair Share berbasis Tri Hita Karana 
(kelompok eksperimen lebih tinggi jika dibandingkan dengan siswa yang dibelajarkan melalui pembelajaran konvensional (kelompok kontrol).

Mengacu kepada temuan penelitian ini, dapat dikemukakan beberapa saran sebagai berikut. 1) hasil penelitian ini menunjukkan bahwa sikap peduli sosial dan kompetensi pengetahuan IPA siswa yang dibelajarkan melalui model kooperatif tipe Think Pair Share berbasis Tri Hita Karana lebih baik jiak dibandingkan dengan sikap peduli sosial dan kompetensi pengetahuan IPA siswa yang dibelajarkan melalui pembelajaran konvensional. Untuk itu model kooperatif tipe Think Pair Share berbasis Tri Hita Karana perlu diperkenalkan dan dikembangkan lebih lanjut kepada guru dan praktisi pendidikan lainnya, 2) kepada guru yang mengajar muatan pelajaran IPA, sebaiknya menggunakan model kooperatif tipe Think Pair Share berbasis Tri Hita Karana dalam mengajar muatan pelajaran IPA untuk meningkatkan kompetensi pengetahuan IPA siswa serta menumbuhkan sikap peduli sosial siswa secara optimal, 3) bagi peneliti lain yang ingin melaksanakan penelitian yang sejenis diharapkan lebih dapat mengembangkan penelitian ini dengan mengembangkan variabel yang lain.

\section{DAFTAR RUJUKAN}

Adnyana, I. G. O, I. M. Tegeh, \& Pt. A. Dharmayanti. 2017. "Pengaruh Model pembelajaran Snoball Throwing Berbasis Kearifan Lokal Terhadap Hasil Belajar IPS Siswa Kelas IV". E-Journal PGSD Universitas Pendidikan Ganesha Mimbar PGSD. Vol. 5. No.2. Tersedia pada file://C:/Uses/Downloa/37-10921-1-SM\%20(1).pdf. Diakses pada tanggal: 3 Januari 2019.

Koyan, I. W. 2012. Statistik Pendidikan, Teknik Analisis Data Kuantitatif. Singaraja: Undiksha Press.

Kurniasih, I \& B. Sani. 2015. Ragam Pengembangan Model Pembelajaran Untuk Meningkatkan Profesionalitas Guru. Kata Pena.

Peraturan Menteri Pendidikan dan Kebudayaan RI No. 22 tahun 2016 tentang Standart Proses Pendidikan Dasar dan Menengah. Kementerian Pendidikan dan Kebudayaan Republik Indonesia. Tersedia pada: http://sosmedpc.blogspot.comS2016/12/lampiran-permendikbudno-24-tahun-2016.html?m=1/. Diakses: 28 Mater 2019.

Samatowa, U. 2016. Pembelajaran IPA di Sekolah Dasar. Jakarta: PT. Indeks.

Peraturan Menteri Pendidikan dan Kebudayaan RI No. 20 tahun 2016 tentang Standart Kompetensi Lulusan Pendidikan Dasar dan Menengah. Kementerian Pendidikan dan Kebudayaan Republik Indonesia. Tersedia pada: http://sosmedpc.blogspot.com/2016/12/lampiran-permendikbudno-24-tahun-2016.html?m=1/. Diakses pada tanggal: 28 Mater 2019

Shoimin, Aris. 2014. 68 Model pembelajaran inovatif dalam kurikulum 2013. Yogyakarta: Ar-Ruzz Media. 